\title{
THE INFLUENCE OF POLITICS AND NATIONALISM ON THE DEVELOPMENT OF WRITTEN LATGALIAN IN THE LONG NINETEENTH CENTURY (1772-1918)'
}

At first glance, the map of Europe in the twentyfirst century is made up of nation-states and federations, homogenous blocks of colour and fixed borders. Yet these do not reveal the whole story. Europe is also a continent of regions, both transnational (e.g. Galicia, Silesia, Polesia or Carpathian Ruthenia) and subnational (e.g. Samogitia, Kashubia or Bavaria) reflecting the poly-ethnolinguistic and multiconfessional reality of the peoples who inhabit these lands. Unlike Europe's fixed political borders, regional identities often cannot be clearly demarcated. They resemble what Benedict Anderson terms 'imagined communities', a sense of personal and collective belonging based on a relationship between identity and place, religion, language, ethnicity and nationality. ${ }^{2}$ Latgale, the region of southeast Latvia, is one such area in which a distinct regional identity distinguishes it from the other parts of Latvia (Kurzeme, Vidzeme, and Zemgale). ${ }^{3}$

Latgale is ethnolinguistically distinct from the western regions of present-day Latvia and, is in many ways, the least 'Latvian'. Firstly, it is a borderland and the meeting place of the frontiers of present-day Belarus, Lithuania, and Russia. ${ }^{4}$ The region is home to a population which is both linguistically (speakers of Latvian, Russian, Latgalian, Polish, Belarusian, and Lithuanian)

Catherine GIBSON, M.A., is a graduate of the University of St Andrews; she is currently completing a Masters at University College London, School of Slavonic and East European Studies. catherine.gibson.13@ucl.ac.uk

1 Work on this article was supported by a scholarship from the Carnegie Trust for the Universities of Scotland, to whom I acknowledge my thanks. Many thanks also to Tomasz Kamusella and Ligija Purinaša for their insightful comments and suggestions. Any errors that remain are my own.

2 Benedict Anderson, Imagined communities: reflections on the origin and spread of nationalism (Revised \& extended ed.) (London: Verso, 1991)

3 Contemporary place names will be used throughout for consistency, however historical and linguistic alternatives will be indicated where appropriate.

4 Latgale also shared a border with Poland from 1922-39. After the Polish-Lithuanian war following World War I, the nominally independent polity of Central Lithuania (1920-22), present-day northeast Lithuania including the city of Vilnius (Wilno), was incorporated into the Second Polish Republic as Wilno Land (ziemia wileńska) (1922-26) and later Wilno Voivodeship (województwo wileńskie) (1926-39). 
and confessionally (Catholics, Protestants, Orthodox, Old Believers, Lutherans, as well as atheists-believers in non-belief, or more broadly, in the Soviet Communist project) diverse. The region also resided historically within the Russian Empire's Pale of Settlement, thus until World War II there were a large number of Yiddish speakers and practisers of Judaism. ${ }^{5}$ Today, although their numbers are greatly diminished, their cultural influence remains. There is also a small number of Roma in the region.

Secondly, among the population of Latgale officially classified by Latvian censuses as 'Latvian', those residing in Latgale have a distinct regional identity based on their Catholic faith (as compared to the predominantly Lutheran Latvians in the western provinces) and their Latgalian language/dialect. ${ }^{6}$ Pēteris Zeile, who has written voluminously on Latgalian cultural history, argues that these linguistic and religious differences make up a distinct Latgalian 'ethnomentality' encompassing culture, psychology, language and traditions, which developed throughout history. ${ }^{7}$ Moreover, Latgale is geographically delimited by three rivers (Daugava, Pededze and Aiviekste), and is distinguished by its historical-political separation from the western regions of present-day Latvia, as a voivodeship (duchy) of the Polish-Lithuanian Commonwealth (known as Inflanty in Polish, and Polish Livonia or Polish Inflanty in English) and later, of the Vitebsk (Vitsebsk) gubernia ('governorate' or administrative district) in the Russian Empire.

Catholic identity in Latgale however is not specific only to Latgalians. It is part of a Catholic culture shared with many speakers of Polish and Belarusian (and also Lithuanian, to a lesser extent) in the region. Equally, Valdis Tēraudkalns has conducted research into the often overlooked Lutheran Latgalians, who have strong religious links to the Protestant Baltic German culture of Livonia ${ }^{8}$ and Courland, and examines figures such as Bishop Kārlis Irbe (1861-1934) who supported the publication of the Gospels in the Latgalian language in $1924 .{ }^{9}$

Instead, it is the widespread use of the Latgalian language/dialect which gives Latgalians their distinct ethnoregional identity vis-à-vis the rest of Latvia. In 2011 UNESCO estimated the number of regular Latgalian users to be 150,000, found mainly in eastern Latvia, ${ }^{10}$ but also in neighbouring cross-border areas of the Russian Federation, in small

5 The Askenazi Jews in this region were also confessionally divided between Hassidim and anti-Hassidim traditionalists (Litvaks).

6 The status of Latgalian today is highly politicized. Officially Latgalian is classified as a dialect of the Latvian language, however arguments are also made by those in Latgale and elsewhere for it being a separate language. The terms 'language', 'dialect' and 'subdialect' are all used in relation to Latgalian by scholars and in the Latvian media; there is no consensus among Latvian and Latgalian scholars as to how to distinguish between the three. See Sanita Lazdina \& Heiko F. Marten, 'Latgalian in Latvia: A Continuous Struggle for Political Recognition', Journal on Ethnopolitics and Minority Issues in Europe, Vol. 11, No. 1 (2012), p. 66-87; Heiko F. Marten, '“Latgalian is not Language": Linguistic Landscapes in Eastern Latvia and how they Reflect Centralist Attitudes', in Durk Gorter, Heiko F. Marten and Luk Van Mensel (eds.) Minority Languages in the Linguistic Landscape (Palgrave Macmillan, 2012), pp. 19-35.

7 Pēteris Zeile, Latgales kultūras vesture (Rēzekne: LKCl, 2006). See Chapter 11

8 Livonia (German: Livland) here refers to the territory of the Livonian Order (1237-1561) which was conquered by Sweden after the Polish-Swedish War (1626-29) and ruled as Swedish Livonia (1629-1721). The territory was formally ceded to the Russian Empire in 1721 after the Great Northern War, named the Riga gubernia (1721-1796) and then Livonia gubernia (Russian: Lifliandskaia guberniia; German: Livländisches Gouvernement; Latvian: Vidzemes guberna) from 1796-1918. This should not be confused with Polish Livonia, used in English to refer to both the Duchy of Livonia (1561-1621), a principality of the Grand Duchy of Lithuania and later the Polish-Lithuanian Commonwealth, and the Inflanty Voivodeship, a district of the Duchy of Livonia (1621-1772) that was retained by the Polish-Lithuanian Commonwealth. The Polish name, Inflanty, was derived from the Polonisation of the German name, Liefland.

9 Valdis Tēraudkalns, 'One's Own People or Strangers: Lutheranism in Latgale during the Period of First Independence of Latvia (1918-1940), Latgale as a Cultural Border Zone: Comparative Studies Vol. II (1), (Daugavpils: Daugavpils University Academic Press Saule, 2009), p. 139.

10 Eastern Latvia here also refers to the small number of Catholic Latgalian speakers in the region of Selonia (Latvian: Sēlija; Lithuanian: Sèla), known historically as eastern Semigallia and Upper Courland, which strad- 
communities in Siberia (deported there by the Soviet regime) and immigrant communities in the USA. ${ }^{11}$ In the 2011 Latvian Census, 164,510 respondents affirmed that they use Latgalian on a daily basis, 7.9 per cent of the total population of Latvia, of which 59.3 per cent were from Latgale. ${ }^{12}$ Among respondents who replied that their home language was 'Latvian' (although according to official definition this encompasses standard Latvian and Latgalian), 71.9 per cent in Latgale claimed they used the Latgalian language/dialect on a daily basis, compared with 1.3 per cent from Kurzeme, 6.0 per cent from Riga, 4.3 per cent from Pieriga, 4.9 per cent from Vidzeme, and 4.7 per cent from Zemgale. ${ }^{13}$ This linguistic regional distinction is not officially acknowledged. As far as the Latvian state is concerned, Latgalians, unlike the Russians, Poles and Belarusians in Latgale, are not a minority as they are 'Latvians'. The Latgalian language is classified as a dialect, 'subtype', and 'historic variant of the Latvian language'. ${ }^{14}$

Valda Čakša however has argued that Latgalian ethnolinguistic identity is especially based on written Latgalian. ${ }^{15}$ Rather than preserving the dialectal continuum of a language in speech and using Latvian for written purposes, the codification of Latgalian into a separate system of writing acts as a visual and systematic form of differentiation. Tellingly, the Latvian census does not include a question about the use of written Latgalian, only 'language spoken'. The importance of written language as a marker of differentiation is a common phenomenon in Central and Eastern Europe, and similar arguments are made about the differences between Czech and Slovak, Moldovan and Romanian, and Bosnian/Serbian/Croatian/Montenegrin. ${ }^{16}$ In these cases, the written form of the languages and the script used to write it are used as an argument for the existence of separate nation-states. Especially in regions with ethnolinguistically diverse and multilingual inhabitants, such as Latgale, language becomes a political statement and symbol of national affinity. Although there has never been a strong or popular movement to use Latgalian as justification for the creation of an independent Latgalian nation-state, ${ }^{17}$ unlike in the case of Slovak, Moldovan, and Bosnian/Serbian/Croatian/Montenegrin, it is widely used as a symbol of regional distinctiveness and autonomy, similar in this function to Ruthenian, Samogitian, Kashubian, Mazurian, Silesian, Polesian or Goralian (Podhalanian). Latgalians refer to this as gruomota, stemming from Old Church Slavonic грамота/gramota, which $13^{\text {th }}-15^{\text {th }}$ centuries, and its inhabitants were assimilated into the Latgalians and Lithuanians. Lidija Leikuma, 'The beginnings of written Latgalian', in Kristiina Ross, Pēteris Vanags (eds.) Common Roots of the Latvian and Estonian Literary Languages (Peter Lang, 2008), p. 211.

11 The UNESCO Atlas of the World's Languages in Danger, 2011, http://www.unesco.org/culture/languagesatlas/index.php [Accessed 1 Oct 2013].

12 'TSG 11-08: Resident population of Latvia by main language spoken at home and use of Latgalian, subtype of Latvian language, on a daily basis by age group', 2011 Latvian Census, Centrālās statistikas pārvaldes datu bāzes, http://data.csb.gov.Iv/Dialog/Saveshow.asp [Accessed 1 Oct 2013].

13 Ibid.

14 Section 3, Official Language Law, December 1999, http://izm.izm.gov.lv/laws-regulations/2292.html [Accessed 1 Oct 2013].

15 Valda Čakša, 'Latgalian Traditional Culture and Regional Identity: Places of Cultural Memory and Symbols', Latgale as a Cultural Border Zone: Comparative Studies Vol. II (1), (Daugavpils: Daugavpils University Academic Press Saule, 2009), p. 122.

16 Robert D. Greenberg, Language and Identity in the Balkans: Serbo-Croatian and Its Disintegration (Oxford University Press, 2008); Tomasz Kamusella, The Politics and Nationalism of Modern Central Europe (Palgrave Macmillan, 2009).

17 At the First Congress of Latgalistics in Rēzekne in April 1917, regional representatives met to discuss the future of Latgale. Francis Kemps (1876-1952), a Latgalian 'national awakener' and his supporters, voiced arguments for an independent Latgale. They walked out of the meeting in protest when the majority of delegates voted in favour of joining the future Latvian nation-state. Andrejs Plakans, 'Regional Identity in Latvia: The Case of Latgale', in Martyn Housden \& David J. Smith (eds.), Forgotten Pages in Baltic History: Diversity and Inclusion (Rodopi, 2011), pp. 55-57. 
is taken from the Greek word gramma meaning character (letter) or written text. In contemporary Latgalian it literally translates as 'book', but it is also used to denote the wider concept of Latgalian literary culture and its importance to regional identity. ${ }^{18}$

Thus, the status of the Latgalian language/dialect today is highly politicised. But this is not only a twenty-first century phenomenon. Since its inception as a written language in the mid-eighteenth century, Latgalian has been shaped by the politics of its day. However, studies of Latgalian gruomota published in English thus far have focused on the development of written Latgalian in the twentieth and twenty-first centuries ${ }^{19}$ or have a linguistic rather than historical focus. ${ }^{20}$ What follows is an exploratory study of the history of written Latgalian during the long nineteenth century, from when it was first printed in the mid-eighteenth century until World War I, and is intended to open up this topic for further research. Historical studies of Latgale thus far have often been conducted within the framework of national historiographical traditions; Latgale is incorporated on the fringes into the history of other political entities: the Polish-Lithuanian Commonwealth, the Russian Empire, and especially the Latvian nation-state. ${ }^{21}$ Instead, this study takes the region of Latgale as its focus, and uses transnational perspectives to contextualise the development of written Latgalian with the development of other written languages in the region, Lithuanian, Samogitian, and Belarusian, as well as Latvian. This attempts to eschew the teleology of the Latvian national master narrative, which portrays Latgale as inherently part of the Latvian nation-state and Latgalian as a dialect of Latvian. It is important to recognise that multiple written languages and national projects had emerged in the region by the beginning of the twentieth century, and that the study of the development of national projects in Latgale in the long nineteenth century should not be limited to just those achieved by a titular nation-state after World War I. It should be noted that due to the constraints of space, this article limits its focus to early printed Latgalian; early handwritten Latgalian has been dealt with elsewhere. ${ }^{22}$

\section{THE EARLY CODIFICATION OF WRITTEN LATGALIAN}

Present-day Latgale is located on the historical territory of the crusading Livonian Brothers of the Sword. Following the defeat of the Brotherhood at the Battle of Saule (1236) at the hands of the pagan Samogitians, the surviving members were incorporated into the Teutonic Order of Prussia in 1237 as an autonomous branch known as the Livonian Order. By the end of the thirteenth century, the Order had conquered Courland, Livonia, and Semigallia, the present-day territory of Latvia. During the Livonian War (1558-1583) between the Tsardom of Muscovy and a coalition comprising Denmark-Norway, the Kingdom of Sweden, and the Union (later Commonwealth) of the Kingdom of Poland and

\section{-.....}

18 Ilga Šuplinska (ed.), Latgolys Lingvoteritorialuo Vuordneica Vol II./Linguoterritorial Dictionary of Latgale Vol. II (Rēzekne: Rēzeknis Augstškola, 2012), p. 229.

19 Plakans, 'Regional Identity in Latvia: The Case of Latgale', pp.49-70; 'The Latgalian language and education in Latvia' (Mercator European Research Centre on Multilingualism and Language Learning, 2009).

20 Anna Stafecka, 'Latgalian writing throughout centuries', Latgale as a Cultural Border Zone: Comparative Studies Vol. II (1), (Daugavpils University Academic Press Saule, 2009), pp. 192-199.

21 Alexandrs Ivanovs, 'History of Latgale within the Context of Political and Ethnic History of the Region', Acta humanitarica universitatis Saulensis, T. 9 (2009) p. 74. See for example: Pēteris Zeile, Latgales kultūras vesture (Rēzekne: LKCl, 2006); Andrejs Plakans, The Latvians (Hoover Press, 1995); Alfred Bilmanis, A History of Latvia (Princeton: Princeton University Press, 1951).

22 Leikuma, 'The beginnings of written Latgalian', pp. 211-233. 
the Grand Duchy of Lithuania, the Order was defeated at the Battle of Ergeme in 1560. The Order sought the protection of Sigismund II Augustus, the King of Poland and the Grand Duke of Lithuania by signing the Treaty of Vilnius (1561), stipulating that the nonDanish and non-Swedish part of Livonia, with the exception of the Free Imperial city of Riga, subject itself to the Polish King and Grand Duke of Lithuania. The last Livonian master, Gotthard Kettler, secularized the Order and converted to Luthernism, later becoming the Duke of Courland and Semigallia. Livonia was incorporated into Poland-Lithuania as the Duchy of Livonia. Estland was seized by Sweden and became the Swedish Duchy of Estonia from 1561-1721.23

From 1561-1569 the Duchy of Livonia was a vassal dependency of the Grand Duchy of Lithuania, and after the Union of Lublin (1569), a joint domain of the Polish Crown and Grand Duchy of Lithuania. From 1598-1621 it was administered as part of the Wenden Voivodeship, and its capital was in Wenden (Polish: Kieś; the present-day Latvian town of Cēsis). During the Swedish-Polish war (1626-1629), the larger part of the Duchy was conquered by Sweden, with the exception of the southeastern region corresponding to the territory of present-day Latgale. The Commonwealth retained the southeastern part of the Wenden Voivodeship, renamed the Inflanty Voivodeship (also popularly known as Polish Inflanty), with its capital in Dyneburg (Polish; present-day Daugavpils). This is the first time that Latgale had existed as an administrative or otherwise defined region. Inflanty remained within the Polish-Lithuanian Commonwealth until the First Partition in 1772, among others, by Catherine the Great's Russian Empire, to which the region was incorporated. Polish Inflanty was initially split between the gubernias of Vitebsk and Pskov until 1885, and then solely administered as part of the Vitebsk gubernia. The situation remained unchanged until World War I. ${ }^{24}$

An alternative way of narrating Latgale's geopolitical history is by looking at the official and administrative languages used by elites in the region, ${ }^{25}$ broadly speaking: Latin and German (13 ${ }^{\text {th }}-16^{\text {th }}$ century), Polish (1561-1772), Russian (1772-1917, and 1940-1989), and Latvian (1917-1940, and since 1990). Latgalian, despite having a writing tradition and gruomota for more than 250 years, has never been an official language, except from 1920-1934 when it was a co-official regional language for local government and education in Latgale during the First Republic of Latvia. ${ }^{26}$

Latgalian was a spoken ethnolect long before it was written. It was part of the Baltic dialectal continuum extending from northern Livonia (bordering on Estonian) to Prussia (bordering on Slavic/Germanic), and is referred to as augšlatvī̌su volūda ('Upper Latvian language') by Latvian and Latgalian scholars. ${ }^{27}$ In this period prior to the writing of vernacular languages, language was not perceived as decisively pertaining to identity. Europeans (with the exception of the narrow stratum of highly mobile nobility and clergy) tended to remain in or near their birthplace, and referred to themselves simply as 'locals' or 'people from here': vietējie (Latvian), mestnyje (Russian), tuteishy (Belarusian), tutejsi (Polish),

\section{......}

23 Kevin O'Connor, The History of the Baltic States (Greenwood, 2003), p. 9-33.

24 For a cartographical representation of the geo-political changes in the history of the region, see Latvijas vēstures atlants [Historical Atlas of Latvia] (Karšu izdevniecība Jāna seta, 2011).

25 Note that this is often different from the most widely spoken everyday language and the language spoken by peasants.

26 Plakans, 'Regional Identity in Latvia: The Case of Latgale', pp. 58-59.

27 The Baltic language group is usually divided by scholars into two sub-groups: Western Baltic comprising only extinct languages (Western Galindian, Old Prussian, Sudovian (Yotvingian), and Skalvian), and Eastern Baltic (Latvian, Latgalian, New Curonian, Lithuanian, Samogitian, Selonian, Semigallian, Old Couronian, and Eastern Galindian). Suplinska, Latgolys Lingvoteritorialuo Vuordneica, p. 370; Endre Bojtár, Foreword to the Past: a cultural history of the Baltic (Central European University Press, 1999), pp. 203-228. 
tuteišiai (Lithuanian), and their language, jezzy tutejszy (language from here), po nashimu, po naszemu (speaking in our own fashion), or prostoi iazyk (simple speech). These were not 'pre-modern' identities as many scholars choose to term them. ${ }^{28}$ Rather these were non-national and non-ethnolinguistic forms of identification, which continued throughout the so-called 'modern' era despite the centralising pressures of nationalism, and continued into the twentieth century. ${ }^{29}$ Moreover, identity was also determined to a large part by religion, for example, to be 'Polish' in the eastern areas of former PolandLithuania meant being of the Catholic faith, (e.g. in Galicia in the nineteenth century, nobles often identified themselves as 'gente Rutheni, natione Poloni', Ruthenian people of the Polish natio). ${ }^{30}$ Language only became an identifying factor when identity increasingly became based on ethnolinguistic definitions.

The initial process of codifying and writing non-imperial vernacular languages in Europe was connected to the Reformation and Counter-Reformation. Protestantism, or the 'religion of the book', prompted the rise of printing in vernacular languages. The first Latvian printed book, of which no copies survive, was a Protestant prayer book from 1525. Latvian language publishing was dominated by the Germanic speaking elites, commonly known as 'Baltic Germans' (Latvian: baltvāciešilvācbalti; German: Baltendeutsche/ Deutsch-Balten), and especially after 1629, was associated with Protestantism and was most frequently printed in the Fraktur type. ${ }^{31} \mathrm{~A}$ Latvian-German dictionary was printed in 1638 and a Polish-Latvian one in 1673. The first book of Latvian grammar was published in $1644 .^{32}$

Written Latgalian only emerged in the eighteenth century through the efforts of the Catholic Church in response to the Protestant Reformation. From the 1560s when Inflanty was incorporated into the Polish-Lithuanian Commonwealth, the region was subjected to the influence not only of Catholicism, 'the Polish faith', but also of the Polish language. Polish had been an official language of the Commonwealth since the Union of Lublin in 1569, but after the 1697 ban on the official use of Ruthenian, Polish became the sole official language in the Grand Duchy of Lithuania. ${ }^{33}$ Although Latin remained the language of international scholarship and diplomatic correspondence, the Reformation spread the use of Polish at the expense of Latin from the mid-seventeenth century. ${ }^{34}$ From its inception as a written language, Latgalian (like Lithuanian and Belarusian used by Catholics) was written in the Latin Antiqua type with Polish spelling. This differed from the development of written Latvian in Courland and Livonia, which was written in Gothic Fraktur type associated with Lutheranism. ${ }^{35}$ The influence of Polish on spoken Latgalian was initially less profound than in the written form, as Polish-speakers were from the landowning class, intellectual elites or officials, and the social barrier was not conducive to close contact with Latgalian peasants. However, many Slavic words gradually made their way into Latgalian

28 For discourse on pre-modern identities, see for example Serhii Plokhy, The Origins of the Slavic Nations: Premodern Identities in Russia, Ukraine, and Belarus (Cambridge University Press, 2010).

29 For example, among the Poleshuks in Polesia.

30 The Latin natio implies the totality of nobles in a polity, rather than the modern-day usage of 'nation'. See for example, Marian Mudryi, "'Rusyny Pol's'koi Natsii" (gente Rutheni, natione Poloni) v Galytsyni XIX st.: I Poniattia "Vitchyzny"' ['The Rusyn Polish Nation (gente Rutheni, natione Poloni) in 19 ${ }^{\text {th }}$ Century Galicia: The concept of "Fatherland"'], Ukraina: Kul'turna spadshchyna, natsional'na svidomist', derzhavnist' No. 15 (2006-2007), pp. 461-473.

31 A kind of Black Letter, associated with emerging Germanness until 1941 when Hitler abolished this type.

32 Kamusella, Politics of Language and Nationalism, p. 194.

33 In the Kingdom of Poland, Latin remained a co-official language.

34 Kamusella, Politics of Language and Nationalism, p. 180.

35 A similar situation developed in the case of Estinian and Southern Estonian (today's Võro/Seto), the latter in Antiqua and influenced by Polish spelling. 
through close contact with the Slavic dialects spoken by Orthodox and Old Believers in the region, in addition to Polish words over the century and a half of Polish-Lithuanian rule. $^{36}$ This differed from Latvian, which was influenced more by the Low German (Plattdeutsch) spoken by the Baltic German elites in Courland and Livonia.

The first known printed book in Latgalian was a Catholic hymnal, Katoliszka Dzismiu gromota Diwam wyssuwarygam por gûdu un Łatwiszym por izmociejszonu sarakstita un izdrukowota (Catholic hymnal written and printed to praise all-powerful God and teach Latvian), published in 1730, however no known copy survives. The earliest Latgalian book preserved today is a collection of translations from Latin (and occasionally from Polish) of gospels and prayers, Evangelica Toto Anno... printed in Wilno (Vilnius) in 1753. ${ }^{37}$ It was printed in the Latin Antiqua type and with Polish orthography, using grave (') and circumflex (^) diacritics. It was complied by a groups of priests, some of whom may have been Jesuits, who had a strong presence in Inflanty and Vilnius, ${ }^{38}$ with diverse competencies of Latvian and Latgalian, the translation has deliberately been done, as the title suggests, to resemble the local inhabitants' 'customary way of speaking', rather than following the written Latvian tradition used in Courland and Livonia which had existed for 200 years. The section at the end of the book contains corrections of mistakes, Errata sic corrige, suggesting that the translators took the task of writing in Latgalian seriously. ${ }^{39}$ The efforts of the Catholic Church to standardize and publish in Latgalian separated the Catholic faithful on the linguistic plane from Latvian-speaking Lutherans.

This non-standardized form of written Latgalian used in Catholic prayer books and written by Catholic priests from outside the region, is typical of the Latgalian texts published throughout the late eighteenth and first half of the nineteenth century. After the Society of Jesus was disbanded in 1773, the Jesuits were suppressed throughout Poland-Lithuania, except in the lands annexed by the Russian Empire in 1772, which included Inflanty, as Catherine the Great forbade the papal decree to be executed. ${ }^{40}$ Boleslavs Brežgo (1887-1957), a Latgalian historian working in the interwar period, compiled inventories of the stock of Church libraries in Latgale using reports of church visitors who mention the most important publications that were used in the Church at that time. He published two further works at V. Lōčis, the first Latgalian publishing house, in Daugavpils in 1943. Although the records of collections that he found were mainly for books in Latin and Polish, he noted key Latgalian publications. For example, in 1770 in the Aglona Domini-

\section{-....}

36 Dorota Krystyna Rembiszewska, 'Polonizmy w totewskich gwarach Łatgalii' ['Polonisms in Latvian dialects of Latgale'], Acta Baltico Slavica, Issue 33 (2009), p. 67; Anna Stafecka, 'Latgalian spelling 100 years ago and currently', Acta Baltico Slavica, 2009, Issue 33, pp. 29-44.

37 Evangelia Toto Anno fingulis Dominicis \& feftis diebus juxta antiquam Ecclesfiæ confvetudinem in Livonia Lothavis prælegi Solita, cum precibus et precatiunculis nonnulis, curâ quorundum ex Clero Livonico recentiffmè juxta usitatiorem loquendi modum Lothavicum versa et translata, Ac in lucem Edita, Anno, quo $æ$ ternum Patris Verbum per Angelos terris evangelizatum eft 1753. [The gospels for the whole year, for every Sunday and for festival days accompanied by the ancient protocol of The Church in Livonia which is accustomed to be patronised by the Lothavi, along with prayers and a few smaller prayers by certain members of the Livonian clergy to which has most recently been added the customary way of speaking among the Lothavi, rendered and translated and raised into the light in that year in which the eternal word of the father was proclaimed to the lands through the angels, 1753.] It is referred to in Latvian and Latgalian scholarship as Asūnes evangéeliji (Gospels of Asūne), after the place where the permission to print it was given.

38 After Livonia was partitioned between Sweden and the Polish-Lithuanian Commonwealth in 1629, the Jesuits moved their Livonian residence from Cēsis, then in Swedish Livonia, to Dyneburg in Inflanty. The Society of Jesus encouraged its members to learn the local language, and the Jesuits became heavily involved in translating in spreading Catholic works among the region's inhabitants. The Jesuits continued to have a strong presence in the area into the early $19^{\text {th }}$ century. Leikuma, 'The beginnings of written Latgalian', pp. 218-221.

39 Stafecka, 'Latgalian writing throughout centuries', pp. 193-4.

40 Leikuma, 'The beginnings of written Latgalian', p. 232. 
can Monastery, Brežgo found records of two Latgalian publications, Evangelia Lothavica and Lingua Rose Lothavicum. In 1820, there was mention of Evangelia polskie i lotevskie (1770) and Lotevska gramatyka, and in 1828, Vysa mocyba Kataliszka (1805). ${ }^{41}$ However, information about early Latgalian printed material is scarce. Records often include only very broad descriptions of a publication, exact publication dates and authors are often unknown, and the same books are frequently listed under multiple titles. ${ }^{42}$ Moreover, Lidija Leikuma suggests that many early printed works in the Latvian State Historical Archives from the seventeenth and early eighteenth centuries, which are catalogued as being written in Latvian, may actually contain Latgalian forms, but as yet, these have not been properly studied. ${ }^{43}$

After Inflanty was incorporated into the Russian Empire in 1772, Russian joined Polish as another prestigious Slavic written language in the region. However, although Inflanty was now part of the Russian Empire's Vitebsk province, linguistically it still remained closely tied to Polish. Polish remained the dominant language of administration, education and law courts in the Russian Empire's partition zone of Poland-Lithuania until the 1830s. Inflanty also retained its ties with the Polish culture of the former Commonwealth through the continuing Catholic tradition in the region. Consequently, the four decades of writing in Latgalian developed within the Polish-Lithuanian Commonwealth continued to strongly influence written Latgalian. For example, during the 1830s, the Polish language underwent reform. Some authors and translators working in Latgalian followed the Polish spelling reforms, which involved replacing the letter (y) with (j). However, this was not followed by all authors, and many continued to follow the eighteenth-century Latgalian orthography influenced by pre-reform Polish spelling, and the letter (y) continued to be used. ${ }^{44}$ This letter remains in Latgalian to this day.

Thus by the late eighteenth century in the territory of present-day Latvia, two forms for writing the Eastern Baltic dialectal continuum existed: 'High Latvian' (augšzemnieku dialekts) in Polish-Lithuanian Inflanty, and 'Middle' or 'Central' Latvian (vidus dialekts), which came to be known as standard Latvian, in Courland and Livonia. ${ }^{45}$ The emergence of multiple written forms for a dialectal continuum spoken by people with different confessional identities was common in this region. Belarusian existed in two written forms until 1918: Latin Antiqua type for Catholics and Uniates, and Cyrillic for Orthodox believers. ${ }^{46}$ In the case of the Lithuanian language, book publishing in Lithuanian began in the western dialect, Aukštaitian ('Highland Lithuanian') spoken by Prussian Lithuanians (Lietuvininkal) living in eastern Prussia, known as Lithuania Minor or Prussian Lithuania. ${ }^{47}$ The

41 Boleslavs Brežgo, Latgales klosteru bibliotēkas un archive [Latgalian monastery libraries and archives], Nr 1. (Rīga: 1940), p. 6. See also, Brežgo, Kaidas latvyskas grōmotas lītōja goreidznīceiba Latgolas katōlu bazneicōs 1757-1888 (Daugavpils: VI. Lōča izdevnīceiba, 1943), pp. 219-221; Brežgo, Latgolas pagōtne Vol I. (Daugavpils: VI. Lōča izdevnīceiba, 1943).

42 Skaidrīte Kalvāne, 'leskats Latgales katolu baznīcu grāmatu krājumos (18.-20. gs)' [Overview of the Catholic Church in Latgalian Book Collections $\left(18^{\text {th }}-20^{\text {th }}\right.$ century)], Via Latgalica: Humanitāro zinātñu žurnāls/Journal of Humanities, Latgalistikys kongresu materiali, II (Rēzekne: Rēzeknis Augstškola, 2010), pp. 29-41.

43 Leikuma, 'The beginnings of written Latgalian', p. 223.

44 Kamusella, Politics of Language and Nationalism, p. 194.

45 Old Couronian, spoken on the Baltic coast, disappeared in the course of the sixteenth century and there are no known written documents in this language.

46 Anna Engelking, 'The natsyas of the Grodno region of Belarus: a field study', Nations and Nationalism, Vol. 5 , Issue 2 (1999), pp. 175-206.

47 The very first printed book in Lithuanian, a catechism, was printed in 1547 in Königsberg (Kaliningrad), and was actually printed in the Samogitian (Žemaitija) dialect because its author Martynas Mažvydas (Martinus Masvidius, Marcin Maszwidas, 1510-1563) came to Prussia from the Grand Duchy of Lithuania. However, this was an exception, and Lithuanian books published in Prussia were generally published in the western Aukštaitian dialect. Kamusella, Politics of Language and Nationalism, p. 181. 
Catholic Church in the Grand Duchy of Lithuania (Lithuania Major) replied to these Protestant initiatives with its own catechism in Lithuanian, published in Wilno (Vilnius) in 1595. It employed the Žemaitija (Samogitian, 'Lowland Lithuanian') dialect in Polish spelling, similar to the later Latgalian effort in 1753. As with the case of Latvian and Latgalian, the divide between the Aukštaitian and Samogitian was reinforced by the use of Gothic type for publications in Lithuania Minor, and Antiqua in Lithuania Major. The extent to which religion influenced written languages meant that until the mid-nineteenth century, Polish lexicographers spoke of two languages: 'Catholic Samogitian' and 'Lutheran Lithuanian'. 48

A similar confessional divide applied to 'Catholic Latgalian' and 'Lutheran Latvian'. However, during this period both were referred to as latviešu valoda (Latvian language) based on the fact that latvietis referred to the ancient Latgalls (Latgalian: latgali, Latin: Lethi, Letthigalli), a Baltic ethnic group or 'tribe' who lived from the $5^{\text {th }}-11^{\text {th }}$ centuries in the region east of the Daugava river. Both the Latvians and Latgalians claimed that they were the descendants of this Baltic ethnic group. ${ }^{49}$ Thus, until the beginning of the twentieth century Latgalians also called themselves 'Latvians' and their language 'Latvian'. The necessity of nominally distinguishing the two languages/dialects and ethnolinguistic groups only emerged alongside the 'national awakening' movements, the Jaunlatviešu kustiba (Young Latvian Movement) in the second half of the nineteenth century and the Latgalian national awakening movement which emerged in the early twentieth century, when the inclusion of Latgale into the Latvian nation-state was debated.

\section{LATIN SCRIPT PRINTING BAN, 1864-1904}

The 1860s brought about two major changes impacting on the development of written Latgalian. Firstly, in 1861 the serfs in the Russian Empire were emancipated. This differed from the serfs in Courland and Livonia who had been emancipated in 1816 and 1819 after the Napoleonic Wars. Emancipation allowed the possibility during the late nineteenth century for freedom to travel, the right to own land and property, more widespread literacy, education and the opportunities of social mobility for peasants. Secondly, Latgalian was subjected to the ban imposed in 1864 on the use of Latin type in the Northwestern Province of the Russian Empire. The print prohibition, which lasted until 1904, was introduced after the 1863-64 'Polish Uprising' in the region as repudiation against the organizers and participants. No official document was ever issued by the imperial administration specifically prohibiting the printing of the Latgalian language in the Latin type, but it was included under the umbrella of 'local idioms' affected by the ban. Being Catholics, Latgalians were treated as Poles, or at least as 'potential Poles', who wrote in the 'Polish script' and thus also deserved discriminatory treatment. ${ }^{50}$ This differed from Lutheran Latvian-speakers, whom the Russian Empire regarded if not as loyal subjects, then as less dangerous than the openly rebellious Poles. For this reason, it was only in 1885 that the imperial administration unsuccessfully attempted to impose the use of Cyrillic for the Latvian language in Courland and Livonia as part of intensified Russification policies

48 'Catholic Samogitian' referred to Catholic Lithuanian in all of Lithuania Major, and not just in Samogitia. Ibid., pp. 182-3.

49 Latvijas vēstures atlantes, pp. 10-11.

50 Šuplinska, Latgolys Lingvoteritorialuo Vuordneica, p. 230. 
in the 1880s. ${ }^{51}$ However, like German, Latvian continued to be written and printed in the Gothic Fraktur type.

Little is known about Latgalian books published in Cyrillic during this period. There are sixty known books published in Lithuanian in Cyrillic from 1864-1905, and it is likely that the number in Latgalian was much less. ${ }^{52}$ There is no library of congress system of transliterating Latgalian in Cyrillic, unlike Lithuanian. ${ }^{53}$ Unlike Belarusian which was written in both Latin and Cyrillic characters until 1918, Latgalian and Lithuanian remained written primarily in the Latin type. The scarcity of Latgalian books printed in Cyrillic is often explained by the fact that the Latgalians were Catholics and rejected their language being written in the type associated with Orthodoxy. It is likely that pragmatic factors also came into play. To start with, there were much fewer books and readers of Latgalian. Many of the Latgalian speakers were peasants, only recently emancipated and many of them illiterate. There was no recognisable Latgalian intelligentsia at this time. In addition, the imperial authorities published books for distribution in the Vitebsk gubernia, however these were most often in Latvian rather than Latgalian, and thus they were viewed by Latgalian readers as not only written in a different type, but in an unfamiliar language/dialect. ${ }^{54}$ One example is a Latvian primer printed in 1864 in Cyrillic to be distributed in Vitebsk gubernia. ${ }^{55}$ The principal publisher of these books was Jānis (Ivan) Sproǵis (1833-1916), a Russified Latvian working for the Russian Empire in Vilna (Vilnius). He admitted in 1887 in a letter to Krišjānis Valdemārs (1825-1891), one of the leaders of the Latvian national awakening movement, that he had not succeeded in adapting Cyrillic to 'Latvian' phonetics ('Latvian', used then still to refer to both Latvian and Latgalian) spoken in the Vitebsk gubernia. ${ }^{56}$

In Latgalian historiography, the development of written Latgalian is frequently portrayed as a victim of external forces. Analysing the problems associated with publishing in Latgalian, Mikelis Bukšs, author of the first cultural history of Latgale, uses the metaphor of 'gruomotu citums' ('book prison'). ${ }^{57}$ This 'book prison' is both external, such as the Russian Empire's Latin type printing ban, and internal, the lack of writers and publishers. However, while the imperial administration had no strong interest in developing Latgalian as a written language in itself, the type ban was not designed to halt the development of written Latgalian, but rather to help Latgalians learn Russian more easily through familiarity with the Cyrillic type, and to distance them from the Polish linguistic and cultural influence. For example, Sprogis published a book of local folksongs, riddles and proverbs, Pamiatniki latyshskogo narodnogo tvorchestva (Monuments of Latvian Folk Art, 1868) for distribution in the Vitebsk province, which was printed in parallel Latvian (in Cyrillic) and Russian text. ${ }^{58}$

\section{......}

51 In 1882-3 Senator N. A. Manasein carried out inspections in Livland and Courland, and the intensified Russification policies were based on his conclusions. Andrejs Plakans, A Concise History of the Baltic States (Cambridge University Press, 2011), p. 258.

52 Giedrius Subačius, 'Development of the Cyrillic Orthography for Lithuanian in 1864-1904', Lituanus (Chicago) Vol. 51, No. 2 (2005), p.29.

53 'Non Slavic Languages (in Cyrillic type)', Library of Congress, http://www.loc.gov/catdir/cpso/romanization/ nonslav.pdf [Accessed 1 Oct 2013].

54 Ëriks Jēkabsons, 'Spaudos lotyniškais rašmenimis draudimas Latvijoje 1865-1904 m.' ''Latin character print prohibition in Latvia, 1865-1904'] in D Staliūnas (ed.), Raidžiu draudimo metai (Vilnius: Lietuvos istorijos instituto leidykla, 2004), p. 194.

55 Darius Staliünas, Making Russians: Meaning and Practise of Russification in Lithuania and Belarus after 1863 (Rodopi B. V., 2007), p. 237.

56 Letter from J. Sprogis to K. Valdemārs, 16 May 1887, RGIA, f. 970, op. 1, d. 1050, I. 15-16. Quoted in Staliūnas, Making Russians, p. 264.

57 Mikelis Bukšs, Latgalu literaturas vesture (Latgalu izdevniceiba, 1957), p.637.

58 Archives of Latvian Folklore (Latviesu folkloras kratuve, LFK), Institute of Literature, Folklore and Art, University of Latvia. http://www.lfk.lv/lfk_eng.html [Accessed 1 Oct 2013]. 
Resistance to the ban on Latin type for the Lithuanian language is widely documented. 3,953 Lithuanian language books in Latin type were produced abroad during the period of the ban, mainly in Prussia $(2,687)$ and the US (712), and smuggled across the border. ${ }^{59}$ The Lithuanian book-smugglers (knygnešys) became part of the Lithuanian national mythology, and a symbol of Lithuanian defiance to Russification. In the Latgale region, defiance to the type ban was on a much smaller scale. To start with, there were many fewer books and readers of Latgalian. Also, the number of Latgalian-speakers living abroad was much smaller than in the Lithuanian case. Nonetheless, handwritten manuscripts are known to have circulated illegally and extensively during this period, for example those by Latgalian poet Pìters Miglinīks (1850-83). ${ }^{60}$

Moreover, there were a number of significant works in Latgalian published outside the area of the Latin script ban. Gustav von Manteuffel (Manteifels) (1832-1916) was a liberal landlord of Baltic German origin (from a family of an old dynasty of Livonian knights) and Polish self-identification who was born in Drycāni, in the historic Inflanty region of the Vitebsk province, $15 \mathrm{~km}$ north of present-day Rēzekne. He published the first calendar in the Latgalian language, Inflantuziemies Łajkagromota aba calendars (Calendar of the Land of Inflanty, 1862-71), in Riga and Tallinn. It is the first and the only nineteenth-century publication in Latgalian to be published regularly, and the last six editions were printed during the period of the Latin type ban. The publisher was fined, but since the calendars were published outside the type ban area, reprisals were less strict than if they have been published within the Vitebsk province. The calendars were popular and included illustrations and practical advice on farming, housekeeping and medicine. They included short stories, riddles, proverbs, poems and folklore, which encouraged people to better themselves by obtaining education and knowledge. The covers of the first calendars (1862-66) depicted a man with a book under his arm opening a curtain onto a panorama of Riga, inviting the reader to discover new intellectual horizons. ${ }^{61}$

Manteuffel also complied the first known bibliography of publications in Latgalian, Bibliographische Notiz über lettische Schriften, welche von 1604 bis 1871 in der hochlettischen ober der sog. oberländischen resp. polnish-livländischen Mundart veröffentlicht worden sind, in rein chronologischer Ordnung zusammengestellt (1885). ${ }^{62}$ It lists the books published in Inflanty and the Russian Empire in the 'Polish-Livonian dialect', although it also includes many books published in Latvian which were circulated in this region. Manteuffel also documented local folklore, traditions and peasant way of life, publishing his research in collections of Latgalian folksongs (Inflantu zemes Laikagrōmota (1862 and 1870)), fairy tales (1862 and 1864) and riddles (1864). He can be considered the first notable publisher of Latgalian literature, and became the inspiration for Latgalian 'national awakeners' once the print ban was lifted in 1904. Moreover, Manteuffel also translated the tsarist government's official pamphlet for the emancipation of the peasants into Latgalian, under the title, Nulikszonas ap ziemnikim izgojuszym nu dzymtigas pidareszonas (The condition of the peasants after the Emancipation of the Peasants Act, 1862), printed in St Petersburg. ${ }^{63}$ Latgalian was thus increasingly used to print secular material. Although this trend started in the 1830s with the first publication of a popular science

59 Subačius, 'Development of the Cyrillic Orthography for Lithuanian', p. 30.

60 Stafecka, 'Latgalian writing throughout centuries', p. 194.

61 Šuplinska, Latgolys Lingvoteritorialuo Vuordneica, p. 236.

62 'A bibliographical note on Latvian writings, which from 1604 to 1871 were published in the High Latvian socalled Polish-Livonian dialect, presented together in purely chronological order'.

63 Šuplinska, Latgolys Lingvoteritorialuo Vuordneica, p. 236. 
book in Latgalian, J. Akielewicz's Eysa mociba ap audzieyszonu biszu (A Short lesson in Beekeeping, 1832), it only gained momentum in the latter nineteenth century.

During the late nineteenth century, ethnographers from outside the region also became interested in Latgalian folklore and published their findings for scientific purposes. This stage in the development of Latgalian printing corresponds to Phase A of Miroslav Hroch's famous ABC schema for the comparative study of nationalisms: A 'period of scholarly interest'; B 'the period of patriotic agitation'; C 'the rise of a mass national movement'. ${ }^{64}$ Examples of such works of Phase $A$ in the case of the Latgalian movement include: Pìters Smelters' A Basket of Folk Songs, Tales, Riddles and Sayings published in Latvian in 1899, Eduards Volters' Materials for Ethnography of the Latvian Tribe of Vitebsk Province published in Russian in 1890, and a Polish volume, Latvians of Polish Livonia, in the edition of the Academy of Science of Kraków entitled Zbiór wiadomości do antropologii krajowej (A collection of messages to national anthropology) in $1891 .{ }^{65}$ All attempt to record Latgalian songs and folklore in the local speech, although not in any standardised manner. ${ }^{66}$ Thus while Endre Bojtár's claim that in the late nineteenth century there was a 'Latgalian Renaissance' seems a little too optimistic, the state of written Latgalian during this period was not as dire as Bukšs' image of the 'book prison' suggests. ${ }^{67}$

\section{THE LATGALIAN NATIONAL AWAKENING}

The Latvian language emerged from the control of the 'Baltic Germans' in the second half of nineteenth century. The expansion of its use as a written language is connected to the first 'national awakening' (tautas atmoda) movement in the 1860s and 1870s, and with the extensive literary output of writers such as Jānis Endzelīns (1873-1961) and Jānis Rainis (1865-1929), and modeled on the German Romanticism of the early nineteenth century. In particular, the cultural philosophy of Johann Gottfried von Herder (1744-1803), who taught at the Riga Dome School from 1765-69, enjoyed an especially strong reputation among the Germanic nobles in the region. They adopted his cultural philosophy of the Latvian-speaking peasants as a suppressed Volk and the Latvian language and oral tradition as encapsulations of the Latvian tauta (people/nation), symbols of 'national revival', and objects of scientific interest. Andrejs Pumpurs' national verse epic, Lāčplēsis (Bear-Slayer, 1888), is an example of the attempt to create a Latvian national mythology based on folklore, following the Estonian example of Kalevipoeg (Kalev's Son, 1853-61), which in turn was based on the epic work of Finish and Karelian oral folklore, The Kalevala (1835; 1849), Finland then within the borders of the Russian Empire.

The Latgalian national awakening movement only gained momentum in the early twentieth century in the years leading up to World War I, and especially in the period after the ban on printing in Latin type was lifted in 1904. In this way, the chronology of the Lat-

64 Miroslav Hroch, Social Preconditions of National Revival in Europe: A Comparative Analysis of the Social Composition of Patriotic Groups Among the Smaller European Nations (Cambridge University Press, 1985).

65 Pìters Smelters, Tautas dzísmu, posoku, meiklu un parunu woceleite (Riga: Katolu māju kalendara, 1899); Eduardas Volteris, Materialy dlia etnografii plemeni Vitebskoi gubernii (St Petersburg, 1890); Stefania Ulanowska, Łotysze Inflant polskich, a w szczególności z gminy Wielońskiej powiatu Rzežyckiego: obraz etnograficzny (Kraków: Drukarnia Uniwersytetu Jagiellońskiego, 1891).

66 Stafecka, 'Latgalian writing throughout centuries', p. 195.

67 Endre Bojtár, Foreword to the Past, p. 174. 
galian national awakening is more similar to the Belarusian national awakening than to the Latvian or Lithuanian, which only emerged as a movement at the turn of the century. ${ }^{68} \mathrm{It}$ was during this period that the development of the Latgalian language became a more widespread issue for the new Latgalian intelligentsia, who were mainly priests and who sought to standardise the written language and publish in Latgalian. Moreover, they were no longer content with the name latviešu valoda ('Latvian language'), and started referring to their language as latgaliešu izloksne ('Latgalian dialect') to distinguish themselves from the speakers of baltiskā izloksne ('Baltic dialect'). At this time, Francis Kemps (Fran,cs Kemps, 1876-1952), nephew of the Latgalian poet Pìters Miglinīks, popularised the use of the territorial name Latgola. For the first time, Latgalian language was being used as an instrument of regionalism and nationalism. The cultural-historical function of written Latgalian was emphasised, the most famous example being Francis Kemps' essay 'Latgalieši' ('Latgalians') (1910), the first cultural history of Latgale, in which he uses language to make an argument for the distinction between of baltieši (Latvians living in Courland and Livonia) and latgalieši (Latvians living in Latgale). ${ }^{69}$

Widespread steps were taken in the early twentieth century to address the 'language problem' and consolidate a standardised system for writing Latgalian. The first conference on Latgalian spelling took place in 1903 in St Petersburg, and in 1908 O. Skrynda published the first book of Latgalian grammar in Latgalian. ${ }^{70}$ The same process was happening with Latvian, and from 1908 specifically Latvian sounds were represented with diacritics borrowed from Czech and Polish $(\overline{\mathrm{a}} / \mathrm{c} / \overline{\mathrm{e}} / \mathrm{g} / \mathrm{I} / \mathrm{k} / \mathrm{l} / \mathrm{n} / \mathrm{s} / \overline{\mathrm{u}} / \mathrm{z})$ in an attempt to diminish the influence, especially in syntax, of Low German, the language of the Baltic Germans who had first codified written Latvian. In addition, Latvian began to be written in Antiqua type rather than in Gothic Fraktur, another move to distance it from German. This had the effect of bringing Latvian and Latgalian closer together in terms of diacritics, syntax and type. However, Latgalian remained distinguished by the letter ' $y$ ', not present in Latvian. After 1957, Latgalian publications retained the letter 'o'' when it was dropped from Latvian. ${ }^{71}$

The early Latgalian 'national awakening' movement had strong connections to St Petersburg (Latgalian: Pìterpil,s). In 1860 the first train between Dvinsk (Daugavpils) and St Petersburg ran, which made it easy for Latgalian intelligentsia from the Vitebsk gubernia to travel there to obtain education. Many Latgalian activists studied in the then Russian capital at the Catholic Spiritual Seminar, including Francis Kemps, Francis Trasuns (18641926), Kazimir Skrynda (1875-1919) and Nikodems Rancāns (1870-1933). In 1908 in St Petersburg, the society Gaisma (Light) was founded, whose aim was to enlighten the people by publishing books, newspapers, organising theatre performances and concerts and founding schools to spread Latgalian. Francis Trasuns taught the Latgalian language to his students at the St Petersburg Theological Seminary. ${ }^{72}$

\footnotetext{
68 Timothy Synder, The Reconstruction of Nations: Poland, Ukraine, Lithuania, Belarus 1569-1999 (New Haven \& London: Yale University Press, 2003), pp. 41-49; 53-54.

69 Šuplinska, Latgolys Lingvoteritorialuo Vuordneica, p. 371.

70 The first book of Latgalian grammar in Latvian was published by J. Akelevičs, Grammatyka Inflanskototewska (Grammar of the Latvian of Inflanty, 1817). Suplinska, Latgolys Lingvoteritorialuo Vuordneica, p. 371. For a comparative and theoretical perspective on language planning, see Joshua A. Fishman, The Earliest Stage of Language Planning: The "First Congress" Phenomenon (Berlin; New York: Mouton de Gruyter, 1993).

71 These were printed by Latgalian émigrés in exile, for example in Munich, as no Latgalian language publications were allowed to be printed in the Soviet Union. Today, in written Latgalian, 'uo' is also used instead of 'ō'. See for example the Latgalian Cultural Newspaper, www.lakuga.Iv [Accessed 1 Oct 2013].

72 Šuplinska, Latgolys Lingvoteritorialuo Vuordneica, p. 206.
} 
The first publication of a newspaper in a language has become a benchmark for national awakening movements in Central and Easter Europe: in Latvian, Mājas Viesis (The House-Guest, 1856) published in Riga; in Lithuanian, Auszra later Aušra (Dawn) from 1883-1886 in East Prussia, and Belarusian Nasha Niva (Our Land, in both Cyrillic and Latin letters) from 1906-1912 in St Petersburg. Francis Kemps published the first Latgalian language newspaper, Gaisma (Light), in St Petersburg, on 27 November 1905. The newspaper's strapline was 'Pyrma latgalīšu awize' ('The first Latgalian newspaper'). ${ }^{73}$ This was the first regular and most influential periodical of the Latgalian 'national awakening'. It was perceived as a revolutionary publication, and was associated with particular literary genres, including the first Latgalian literary fairy-tale by G. Mukts-Kveders, 'Palāda' ('The Owl') and the first historical story, 'Komturs Rodrigs' ('Grand Master Rodrigue') by K. Daugule-Kempa. ${ }^{74}$ At the same time, the clergy organised the publication of two other Latgalian newspapers also published in St Petersburg: Sākla (The Seed), a Catholic newspaper edited by N. Rancāns (1870-1933) and published between February and April 1906, which aimed at educating the peasants ${ }^{75}$; and Auseklis (Morning Star), edited by Francis Trasuns, and which was published weekly from $17^{\text {th }}$ March 1906 until $20^{\text {th }}$ September 1907. ${ }^{76}$ However, three publications proved too much for the readership to sustain. Gaisma only ran for 26 issues, the last being on 15 June 1906. ${ }^{77}$

In 1907 the Latgalians were left without a newspaper, unable to read the Gothic Fraktur type still used to write Latvian at this time. The only Latgalian language articles being published were in the small magazine Zemkopis (Farmer). The Catholic clergy decided to issue the newspaper Drywa (Cornfield) under the editorial of seminarian Kazimir Skrynda. First published in St Petersburg on 15 th May 1908, it was aimed at a peasant readership and it was distributed through the Catholic Church. At first it was only published monthly. In 1909 this was increased to fortnightly, then three times a month in 1910. In 1911 it was published once a week during the winter, and fortnightly in summer. From 1913 it was published weekly. Topics of the articles it published included religion, economics, farming, health and education, as well as fiction. In 1917, the clergy in Rēzekne bought a printing press, and on $22^{\text {nd }}$ April 1917 the first Latgalian newspaper printed in Latgale rolled off the press. The last issue came out on $21^{\text {st }}$ December 1917 after the Bolshevik Revolution. ${ }^{78}$

During World War I, Courland was occupied by the German armed forces and administered as part of Ober Ost, along with Lithuania and Bialystok-Grodno, where Berlin pursued a policy of supporting national movements in order to prevent Russian rule returning to the region. ${ }^{79}$ The Latgale region remained as part of the Russian Empire and then

73 'Gaisma': pirmā latgaliešu avīze', Rēzeknes Centrālā Bibliotēka, http://www.rezeknesbiblioteka.Iv/index. php?option=com_content\&view=article\&id=507: gaisma-pirma-latgaliesu-avize\&catid=163: par-izstademcb\&ltemid=276 [Accessed 1 Oct 2013].

74 Šuplinska, Latgolys Lingvoteritorialuo Vuordneica, p. 208.

75 Sākla, 1906, National Library of Latvia, http://data.Inb.Iv/digitala_biblioteka/laikraksti/Sakla/index.htm [Accessed 1 Oct 2013].

76 Auseklis, 1906-1907, National Library of Latvia, http://data.Inb.Iv/digitala_biblioteka/laikraksti/Auseklis/index. htm [Accessed 1 Oct 2013].

77 However the ideological importance of 'Gaisma' was continued symbolically through the names of other press publications. For example, from 1968-1996 a Catholic journal was published in Leuven in Belgium under the same name, and was an important element of Latgalian culture in exile. Today, 'Gaisma' is the name of the schools newspaper of the Rēzekne Catholic High School and the Rēzekne Society of Culture publishes a newspaper called 'Gaisma taka' ('Light Trail'). Šuplinska, Latgolys Lingvoteritorialuo Vuordneica, p. 209.

78 New-style date. Drywa, 1908-1917, National Library of Latvia, http://data.Inb.Iv/digitala_biblioteka/laikraksti/ Drywa/index.htm [Accessed 1 Oct 2013].

79 Oberbefeh/shaber der gesamten Deutschen Streitkräfte im Osten (Supreme Commander of All German Forces in the East), referred not only to the commander, but also to his governing military staff and the 
Bolshevik Russia until the Treaty of Brest-Litovsk (1918) between the German Empire and Bolsheviks, whereby the Bolsheviks renounced the Russian Empire's claims to its western territories, the future nation-states of Poland, Finland, Estonia, Latvia, Belarus, Ukraine and Lithuania. Latvia was included in the proposed Baltic German-led United Baltic Duchy, but this collapsed after the defeat of the German Empire in November 1918. The post-war confusion provided the opportunity for Latvia to proclaim independence on $18^{\text {th }}$ November 1918.

In the last years of World War I, the establishment of an autonomous and independent Latvia had been under discussion. In March 1917 at the First Latgalian Congress in Rēzekne, a general meeting of 238 delegates from diverse Latgalian organisations voted in favour of joining the Latvian nation-state. Yet the resolution passed still highlighted the Latgalians' strong desire for considerable autonomy in whatever new language-based political formation would emerge. A significant minority of attendees, led by Francis Kemps, walked out, desiring a stronger statement of separateness, expressing a fear among Latgalian activists that joining Latvia as the third star would jeopardise their traditional way of speaking and writing if Latgale were to join the Latvian nation-state.

There was one final claim to the territory of Latgale during the long nineteenth century, a keynote to the development of Latgalian language and its relationship to nationalism and politics, which has been often overlooked. Between 1918-1920 the territory of Latvia was the stage for a series of conflicts between the provisional Latvian government (supported by Estonia, Poland, and the Western Allies, especially the United Kingdom), the Russian Socialist Federative Sociality Republic (RSFSR) and the Bolshevik's short-lived Latvian Socialist Soviet Republic (LSSR), as well as Baltic Germans keen to ensure their influence in whatever post-war polity emerged. This is known in Latvian historiography as the 'Latvian War of Independence' (Briviibas cinas), and lasted until $11^{\text {th }}$ August 1920, where according to the Latvian-Soviet Peace Treaty (Treaty of Riga), Soviet Russia relinquished authority over the Latvian nation and claims to Latvian territory 'forever'. ${ }^{80}$ However, from 25 $5^{\text {th }}$ March 1918 to $5^{\text {th }}$ January 1919, southeast Latgale fell within the territory claimed by the short-lived Belarusian People's Republic (1918-1919). ${ }^{81}$ As outlined by the Third Constituent Charter of the BNR:

The Belarusian Democratic Republic should include all those lands where the Belarusian people constitute a numerical majority, namely: the Mahiloŭ region, the Belarusian parts of the regions of Miensk, Horadnia (including the cities of Horadnia, Bielastok, and others), Vilnia, Viciebsk, Smalensk, and Charnihau, as well adjacent parts of neighbouring gubernias, inhabited by Belarusians. ${ }^{82}$

The Belarusian People's Republic was replaced by a Communist government in January 1919, and the Rada (Council) went into exile. This Belarusian national claim to the territory of Latgale in 1918-1919 serves as a pertinent reminder to the multiple ethnolinguistic national projects that developed in this region in the course of the long nineteenth century.

\section{-.....}

eastern front they controlled. Vejas G. Liulevicius, War Land on the Eastern Front: Culture, National Identity, and German Occupation in World War I (Cambridge, UK; New York: Cambridge University Press, 2000).

80 'Peace Treaty between Latvia and Russia', Rīga, August 11, 1920, Article II, http://www.mfa.gov.Iv/en/ policy/peace-treaty/ [Accessed 1 Oct 2013].

81 Also known historically as the White Ruthenian Democratic Republic, and Belarusian Democratic Republic to distinguish it from the similarly named communist republics.

Latvijas vēstures atlantes, p. 36.

82 '3rd Constituent Charter of the BNR Rada', http://www.radabnr.org/en/archive/3hramatapic.htm [original]; http://www.radabnr.org/en/archive/3hramataen.htm [English translation]; [Accessed 1 Oct 2013]. 
By 1919, 358 publications had been printed in Latgalian. ${ }^{83}$ This number is small when compared with the number published by that time in Lithuanian and Latvian, but not insignificant. Throughout three political regimes-Poland-Lithuania (1629-1772), Russian Empire (1772-1918) and into first Republic of Latvia (1918-1940)_a continuous tradition of Latgalian gruomota was maintained. During this period, Latgalian remained closely tied to the Catholic Church in terms of those producing written texts in Latgalian and their content. However changes in orthography, spelling, type and distribution were heavily influenced by political circumstance and nationalism.

The incorporation of Latgale into the first Latvian Republic in 1918 was not a death knell for Latgalian. In the 1920s the use of Latgalian outside the family flourished in Latgalian schools, administration, public events, press and church. From 1920-1935, Latgalian was made a co-official language for the first and only time in the local self-government and education in Latgale as part of the government's policy of minority rights. After the 1934 coup by Kārlis Ulmanis and the establishment of an authoritarian regime in Latvia, this flourishing was cut short. Ulmanis' regime castigated Latgalian as an obstacle to fulfilling the ethnolinguistic 'all unity' of the Latvian nation-state. ${ }^{84}$ This unofficial ban on Latgalian persisted throughout the Soviet era as well, and Latgalian gruomota was maintained by the activities of Latgalian émigrés in exile, in which Munich became a prominent centre. ${ }^{85}$ After Latvia regained independence in 1991, Latgalian underwent a revival. Latgalian is widely used today in Latgale as a means of everyday communication and as a symbol of regional identity. In its written form it can be found in books, scholarly works published in Latgale, café menus, brochures, and souvenirs. From 2006, the regional radio station, Latgolys Radeja, broadcast Latgalian music and news from Rēzekne. In the twenty-first century, the internet allows the use of Latgalian without restrictions, and there are many webpages and blogs in Latgalian, including Latgalian Wikipedia. ${ }^{86}$

Latvian language politics today are dominated by debates over the status of the Russian language in Latvia. Latgalian is often forgotten outside Latgale, and by extension, even more so outwith Latvia. This article attempts to highlight that, as in the case of Russian, Latgalian language, politics and nationalism are closely interlinked, and this has been the case since Latgalian was first printed in the mid-eighteenth century. It also forefronts the importance of recognising the multiple written languages and national projects which emerged in the region in the long nineteenth century, the truncated or unsuccessful national movements which according to Miroslav Hroch's ABC schema only progressed to phases $A$ or $B$, rather than just the national awakening movements that are familiar to us because they succeeded in forming titular nation-states. ${ }^{87}$ Importantly, this article argues that transnational historical approaches need to be applied to the study of ethnolinguistic nationalism in Central and Eastern Europe in order to shed light on the interactions be-

\section{......}

83 Šuplinska, Latgolys Lingvoteritorialuo Vuordneica, p. 229

84 Aldis Purs, 'The Price of Free Lunches: Making the Frontier Latvian in the Interwar Years', The Global Review of Ethnopolitics, Vol. 1, No. 4 (June 2002), pp. 60-73.

This was part of the popular rhetoric of the authoritarian regimes that emerged in interwar Central and Eastern Europe, for example Hitler's policy of Volksgemeinschaft ('people's community') as a ideology for building an ethnolinguistically homogenous nation-state.

85 For more detail on this period, see Plakans, 'Regional Identity in Latvia: The Case of Latgale', pp. 49-70.

86 Latgalu Vikipedeja [Latgalian Wikipedia], http://ltg.wikipedia.org/wiki/Suoku_puslopa [Accessed 1 Oct 2013].

87 Hroch, Social Preconditions of National Revival in Europe. 
tween different written languages and national projects, whose mutual influences can only be understood within the context of history and the changes in political boundaries.

The Latgalians have never had a strong movement expressing a desire for their own titular nation-state. Instead, Latgalian activism thus far has always been orientated towards campaigning for regional autonomy and recognition of their regional language in Latvia and, to a much lesser extent earlier, within the Russian Empire. This challenges the view that ethnolinguistic nationalism in Central and Eastern Europe is directed solely towards each ethnolinguistic group having their own nation-state in fulfilment of what Tomasz Kamusella terms the 'normative isomorphism' of language, nation and state. ${ }^{88}$ The case of Latgale might provide a useful comparison in future research with other Central and Eastern European regional languages/dialects such as Ruthenian, Samogitian, Kashubian, Mazurian, Silesian, Polesian and Goralian (Podhalanian), whose speakers are likewise without, and for the most part undesiring of, a titular nation-state. ${ }^{89}$ This could suggest an alternative 'isomorphism' in Central and Eastern Europe of language and region, occurring both within states and transnationally.

Latgale today is in many ways a throwback to the multilingual European empires of the eighteenth and nineteen centuries - the Polish-Lithuanian Commonwealth, the Austro-Hungarian Empire, and the Russian Empire-in which citizenship (subjecthood) and nationality (ethnicity) are not taken to mean the same thing. Latgalians retain this imperial dual civic and ethnolinguistic identity: they view themselves as Latvian citizens but part of the Latgalian nation, encompassing their distinct gruomota and cultural heritage. This pertains not only to Latgalians, but inhabitants of many different ethnolinguistic identifications residing in Latgale. In Daugavpils, the largest city in Latgale, there are active centres and community groups dedicated to preserving the culture of the Latgalian, Latvian, Russian, Polish, Belarusian, Ukrainian, German, Jewish and Roma residents, which are all supported by the Daugavpils City Council. ${ }^{90}$ This reminder of the fact that Latvia's population are not homogenously 'Latvian' is written into the Latvian Constitution, which is addressed to Latvijas tauta ('The People of Latvia'), referring to its citizens, rather than 'Latvians' in the ethnolinguistic sense. ${ }^{91}$

GRUOMOTA: THE INFLUENCE OF POLITICS AND NATIONALISM ON THE DEVELOPMENT OF WRITTEN LATGALIAN IN THE LONG NINETEENTH CENTURY (1772-1918)

\section{Summary}

Latgale, the southeast region of Latvia, has a distinct ethnoregional identity largely due to the widespread use of the Latgalian language/dialect. The status of Latgalian as a language/dialect is highly politicised in Latvia today, yet this is not only a twenty-first century phenomenon. Since its inception as a written language in the mid-eighteenth century, the development of written Latgalian has been strongly influenced by politics and nationalism. This is an exploratory paper, which traces the impact

88 Kamusella, Politics of Language and Nationalism, pp. 29-37.

89 Lazdina and Marten also make this suggestion for future comparative research. Lazdina \& Marten, 'Latgalian in Latvia: A Continuous Struggle for Political Recognition', p. 79.

90 'Multinacionālā kultūra', Daugavpils City Council, http://www.daugavpils.Iv/lv/97 [Accessed 1 Oct 2013].

91 'The Constitution of the Republic of Latvia', http://www.saeima.Iv/en/legislation/constitution [Accessed 1 Oct 2013]. 
of politics and nationalism on the development of written Latgalian throughout the long nineteenth century, a period in which the region was administered by three political regimes (Polish-Lithuanian Commonwealth, Russian Empire, First Republic of Latvia). Transnational perspectives are used to contextualise the development of written Latgalian with the development of other written languages in the vicinity (Belarusian, Latvian, Lithuanian, and Samogitian), and to open up the field for further comparative studies on the development of non-national written languages/dialect. Latgale is a borderland region often neglected in mainstream Latvian scholarship, and by extension, even more so outside Latvia. This paper hopes to go some way to rectifying this.

Keywords: Latgale, politics of language, regional identity, nationalism, transnational history

\title{
GRAMOTA: WPLYW POLITYKI I NACJONALIZMU NA ROZWÓJ ŁATGALSKIEGO JĘZYKA LITERACKIEGO W DLUGIM WIEKU XIX (1772-1918)
}

\author{
Streszczenie
}

Łatgalię, południowo-wschodni region Łotwy, cechuje odrębna tożsamość etniczno-regionalna, przede wszystkim z racji powszechnego na tym terenie używania języka/dialektu łatgalskiego. Status łatgalskiego jako języka/dialektu stanowi w dzisiejszej Litwie w dużej mierze kwestię o wymiarze politycznym, aczkolwiek nie jest to zjawisko, które pojawiło się dopiero w XX stuleciu. Łatgalski już od czasu swych narodzin jako język literacki w połowie XVIII wieku pozostawał pod silną presją polityki oraz nacjonalizmów. Niniejszy artykuł ma na celu prześledzenie oddziaływania polityki i nacjonalizmu na kształtowanie się literackiej odmiany języka łatgalskiego w ciągu "długiego wieku XIX" - okresu, w którym region ten podlegał administracji rządowej sprawowanej przez trzy systemy polityczne (Rzeczpospolita Obojga Narodów, Imperium Rosyjskie, Pierwsza Republika Litewska). Spojrzenie na omawiane zagadnienie z perspektywy ponadnarodowej pozwala stworzyć kontekst rozwoju łatgalskiego języka literackiego w odniesieniu do innych języków literackich formujących się w bliskim jego sąsiedztwie (białoruskiego, łotewskiego, litewskiego i semigalskiego), jak też otworzyć pole dla kolejnych studiów porównawczych nad kształtowaniem się nienarodowych języków/dialektów literackich. Łatgalia stanowi region pograniczny, zwykle zaniedbywany przez główny nurt nauki łotewskiej, a tym bardziej w dociekaniach naukowych poza granicami Łotwy. Niniejszy artykuł ma za zadanie choć w pewnej mierze stan ten naprawić.

Przekład z jęz. ang. Jacek SERWAŃSKI 